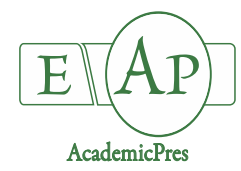

Salcido-Martinez A et al. (2020)
Notulae Botanicae Horti Agrobotanici Cluj-Napoca 48(4):2167-2181
DOI:10.15835/48412090
Research Article

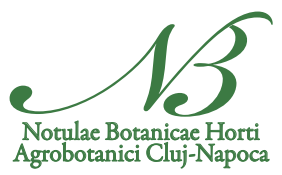

\title{
Impact of the foliar application of magnesium nanofertilizer on physiological and biochemical parameters and yield in green beans
}

\author{
Alondra SALCIDO-MARTÍNEZ ${ }^{1}$, Esteban SÁNCHEZ ${ }^{2 *}$, \\ Lorena P. LICÓN-TRILLO ${ }^{1}$, Sandra PÉREZ-ÁLVAREZ ${ }^{1}$, \\ Alejandro PALACIO-MÁRQUEZ ${ }^{2}$, Nubia I. AMAYA-OLIVAS ${ }^{3}$, \\ Pablo PRECIADO-RANGEL ${ }^{4}$ \\ ${ }^{1}$ Universidad Autónoma de Chihuahua, Facultad de Ciencias Agrícolas y Forestales, Km. 2.5 carretera a Rosales, Poniente, 33000 \\ Delicias,Chihuahua,México; a305744@uach.mx;llicon@uach.mx; perezalvarezsandra2015@gmail.com \\ ${ }^{2}$ Centro de Investigación en Alimentación y Desarrollo A.C. Unidad Delicias, Av. Cuarta Sur 3828, Fracc. Vencedores del Desierto. \\ 33089 Delicias, Chihuahua,México; esteban@ciad.mx (*corresponding author); alexmarquezmj8@gmail.com \\ ${ }^{3}$ Universidad Autónoma de Chihuahua, Facultad de Ciencias Agrotecnológicas, Campus Universitario I, 31000, Chihuahua, \\ Chihuahua, México;p232602@uach.mx \\ ${ }^{4}$ Tecnológico Nacional de México- Instituto Tecnológico de Torreón (ITT), 27170 Torreón, Coahuila, \\ México;ppreciador@yahoo.com.mx
}

\begin{abstract}
One of the most significant challenges humanity will face is food production. In order to preserve the output, mineral fertilizers are essential. However, it's not a suitable option in the long term. Magnesium is a crucial macronutrient, but it is the most limiting element in agriculture. Nanotechnology, with the implementation of nanofertilizers, is an excellent alternative since it provides nutrients, supports growth, and improves production; this in low amounts is more sustainable than conventional fertilizers. Although there is a piece of limited information regarding the proper foliar application of this macronutrient, the study helped to validate the effect of the foliar application of Magnesium nano fertilizer on the physiological, biochemical responses and yield of bean plants. Bean plants ejotero cv. 'Strike' and magnesium nanoparticles were applied at doses of $0,50,100$, and $200 \mathrm{ppm}$. The biomass accumulation, yield, activity of the enzyme nitrate reductase, and photosynthetic pigments were evaluated. The foliar application of Mg nanoparticles at $50 \mathrm{ppm}$ generated the highest amount of biomass and photosynthetic pigments. The $100 \mathrm{ppm}$ dose improved pods yield and allowed the increased activity of the Nitrate Reductase enzyme. The results obtained suggest that, when increasing the dose of magnesium in plants, the amount of carotenes decreases.
\end{abstract}

Keywords: chlorophyll; nanoparticles; Phaseolus vulgaris L.; nanotechnology

\section{Introduction}

The common bean (Phaseolus vulgaris L.), belonging to the Fabaceae family, is the most important legume for direct consumption in the world, mainly for the South American and African zones (de la Fuente 
et al., 2012); It is found in tropical and subtropical regions (Cardona et al., 1995). Beans are grown primarily to be consumed as dry grain and to a lesser extent it is used for food such as fresh seeds and tender pods (Silbernagel et al., 1991; Esquivel et al., 2006). In Mexico for the year 2018, about $66 \%$ of bean production was concentrated in the states of Zacatecas, Sinaloa, Durango, and Chihuahua, occupying the third position in importance for the area planted and the thirteenth position for the value of the national agricultural production, with a total yield of 1,196 million tons (FIRA, 2019).

However, its large-scale application as a chemical fertilizer to increase the productivity of crops is not an appropriate option in the long term, since although, on the one hand, they increase the production of the crop, on the other they disturb the mineral balance of the soil and decrease fertility; Likewise, the use of most macronutrient fertilizers by the plant is very low due to its investment in insoluble form in the soil (Solanki et al., 2015). Magnesium (Mg) is a key macronutrient, since it plays a crucial role in the manipulation of compounds such as ATP, RNA and DNA, however, it is one of the minerals lacking in human diets, positioning itself as the most limiting macronutrient in agriculture and to which less attention has been paid in recent decades (Shinde et al., 2018). Magnesium is essential as a structural component or enzymatic cofactor in plants (Rathore and Tarafdar, 2015), substantial in the light and dark reactions of photosynthesis, because it is the central atom in the chlorophyll molecule (Singh et al., 2017). Chlorosis of fully expanded leaves is the most visible symptom of $\mathrm{Mg}$ deficiency. Also, $\mathrm{Mg}$ deficiency results in a lower proportion of protein $\mathrm{N}$. (Marschener, 2012). Therefore, foliar fertilization of mineral elements, like Mg, is an alternative approach to the use of fertilizers in the soil (White and Broadley, 2009); but this action supported by a growing science called nanotechnology.

Nanotechnology provides novel applications in biotechnology and agriculture, since the transformation of macromaterials to nano-sized particles leads to useful characteristics (Khan and Rizvi, 2014). For agriculture, it is a great alternative for sustainable practice, since it has developed nanofertilizers, these are materials that provide plants with one or more nutrients, support their growth and improve production (Liu and Lal, 2015). The application of nanofertilizers facilitates their absorption by plants due to their slow release, in addition to being effective in very low portions (Kaul et al., 2012; Butt and Naseer, 2020). In recent years, the development and exploitation of nanofertilizers has gained much importance over traditional fertilizers due to their lower environmental impact macronutrient nanofertilizers have a high priority since they offer sustainable development by renewing management and conservation tactics with less waste of agricultural inputs, and in addition to increasing low levels of minerals, in particular Mg (Shang et al., 2019; Butt and Naseer, 2020).

In studies carried out with magnesium nanofertilizers in Stevia rebaudiana Bertoni, an increase in the production of steviosides was found; other research conducted on black-eyed pea or Vigna unguiculata ssp. (Delfani et al., 2014), showed greater mobility and absorption capacity of the Mg nanofertilizer; the content of total chlorophyll in wheat or Triticum aestivum L. was improved (Rathore and Tarafdar, 2015). However, it has also been found that the excessive application of Magnesium can be detrimental to the membrane and can alter the functioning of the photosynthetic system (Shabala and Haiadi, 2005). Therefore, it is extremely important to carry out studies that compare the effect of different doses of magnesium nanofertilizer, since the literature on this research topic is scarce.

Despite the few studies, nanofertilizers are already in commercial form, so the aim of this study was to validate the effect of the foliar application of Magnesium nanofertilizer on the physiological, biochemical responses and yield of plants of green beans cv. 'Strike'.

\section{Materials and Methods}

\section{Crop management}

The study was carried out at the facilities of the Center for Research in Food and Development (CIAD), located in cd. Delicias, Chihuahua, Mexico. For the experiment, seeds of green beans (Phaseolus vulgaris L.), Var: 'Strike', a shrub plant with determined growth and straight pods were used, this variety was selected for 
being were short-cycle and easy to handle. In the first place, four seeds were sown in plastic pots with a capacity of $13.4 \mathrm{~L}$, provided with an inert substrate, vermiculite, and perlite, in a 2:1 ratio. The pots were left exposed to the environmental conditions of the field. After germination, only two plants were left per pot. These were watered every third day with $500 \mathrm{~mL}$ of nutrient solution, increasing the volume to $1000 \mathrm{~mL}$ once the flowering stage arrived, maintaining a $\mathrm{pH}$ of $6.0 \pm 0.1$, and with the formulation presented in table 1.

Table 1. Formulation of nutritive solution, used by Sánchez (2006)

\begin{tabular}{|c|c|}
\hline Macronutrients & Micronutrients \\
\hline $6 \mathrm{mM} \mathrm{NH}_{4} \mathrm{NO}_{3}$ & $1 \mu \mathrm{M} \mathrm{ZnSO}_{4}$ \\
\hline $1.6 \mathrm{mM} \mathrm{K}_{2} \mathrm{HPO}_{4}$ & $5 \mu \mathrm{M} \mathrm{Fe}-\mathrm{EDDHA}_{4}$ \\
\hline $0.3 \mathrm{mM} \mathrm{K}_{2} \mathrm{SO}_{4}$ & $2 \mu \mathrm{MnSO}_{4}$ \\
\hline $4 \mathrm{mM} \mathrm{CaCl}_{2}$ & $0.25 \mu \mathrm{M} \mathrm{CuSO}_{4}$ \\
\hline $1.4 \mathrm{mM} \mathrm{MgSO}_{4}$ & $0.3 \mu \mathrm{M} \mathrm{Na}_{2} \mathrm{MoO}_{4}$ \\
\hline & $0.5 \mu \mathrm{M} \mathrm{H}_{3} \mathrm{BO}$ \\
\hline
\end{tabular}

\section{Experimental design and treatments}

A completely randomized experimental design was used with four $\mathrm{PHC}^{\circ} \mathrm{Nano} \mathrm{Mg}$ treatments at doses of $0,50,100$ and $200 \mathrm{ppm}$ and four repetitions each, generating a total of 16 experimental units. The treatments were applied by foliar application every 10 days from the appearance of the true leaves.

The material applied as nanofertilizer was the commercial product $\mathrm{PHC}^{\circ} \mathrm{Nano} \mathrm{Mg}$, which is a suspension, where the $\mathrm{Mg}$ is available in ionic form, with nanoparticle size between 500 and 2000 nanometers.

\section{Plant sampling}

At the physiological maturity of the plants, 60 days after germination, the plant samples were collected and rinsed twice, once with distilled water and the second with tri-distilled water; the material was divided into two parts, dry material, and fresh material. The dry material was used for the analysis of biomass in dry matter, while the fresh material was used to determine the yield, biomass in fresh matter, analysis of physiological and biochemical indicators (enzymatic activity).

\section{Plant analysis}

\section{Biomass}

The total biomass production of the different organs was determined, they were first weighed fresh at harvest time, later they were subjected to a decontamination process, and for this they were cleaned with abundant deionized water. Then, they were introduced to a drying oven (Shell) at a temperature of $70 / 80^{\circ} \mathrm{C}$ and until they had completely dried $(16 / 24 \mathrm{~h})$, to finally proceed to weigh and obtain the dry weight $(\mathrm{g})$ of each organ.

\section{Yield}

The plant yield was expressed as the average weight of fresh fruit per plant. The green pods collected from each plant were weighed at sampling. Total production was reported as grams per plant.

\section{Nitrate reductase activity "in vivo"}

In a reduction process, the enzyme Nitrate Reductase transforms nitrates $\left(\mathrm{NO}_{3}{ }^{-}\right)$into nitrites $\left(\mathrm{NO}_{2}{ }^{-}\right)$. To quantify it, the method proposed by Sánchez (2006) was used. The leaves were cut into cylindrical sections of $5 \mathrm{~mm}$ in diameter and the sample was placed in $10 \mathrm{ml}$ of incubation buffer $(10 \mathrm{mM}$ of $100 \mathrm{mM}$ potassium phosphate buffer, $\mathrm{pH} 7.5)$ and $1 \%(\mathrm{v} / \mathrm{v})$ of propanol. The samples were infiltrated, and the intracellular spaces of the tissues were washed with buffer using a vacuum $(0.08 \mathrm{MPa})$. After five minutes, the vacuum was released, and the samples were re-evacuated; they were incubated at $30{ }^{\circ} \mathrm{C}$ in the dark for one hour and then placed in boiling water to interrupt Nitrate Reductase (NR) activity. $\mathrm{NO}_{2}{ }^{-}$were determined by spectrophotometry at 
$540 \mathrm{~nm}$ in a reaction mixture consisting of $2 \mathrm{~cm} 3$ of extract, $2 \mathrm{~cm}^{3}$ of $1 \%$ sulfanilamide $(\mathrm{m} / \mathrm{v})$ in $1.5 \mathrm{M} \mathrm{HCl}$ and $2 \mathrm{~cm}^{3} 0.02 \%(\mathrm{~m} / \mathrm{v}) \mathrm{N}-\left(1-\mathrm{N}\right.$ aphthyl dihydrochloride)-ethylenediamine in $0.2 \mathrm{M} \mathrm{HCl}\left(\mathrm{NR}+\mathrm{NO}_{3}{ }^{-}\right)$, following the same method but using a modified incubation buffer containing $50 \mathrm{mM} \mathrm{KNO}_{3}$. The NR induced by $\mathrm{NO}_{3}{ }^{-}$and $\mathrm{Mo}\left(\mathrm{NR}+\mathrm{NO}_{3}{ }^{-}+\mathrm{Mo}\right)$, and the $\mathrm{NR}$ induced by $\mathrm{NO}_{3}$ and $\mathrm{Mo}\left(\mathrm{NR}+\mathrm{NO}_{3}{ }^{-}+\mathrm{Mo}\right)$, were also determined using a modification of the incubation buffer containing $20 \mathrm{mM} \mathrm{NaMoO}_{4}$ and $\mathrm{KNO}_{3}$ plus $50 \mathrm{mM}$ $\mathrm{NaMoO}_{4} 20 \mathrm{mM}$, respectively. The resulting nitrate concentration was also determined spectrophotometrically.

\section{Photosynthetic activity}

Photosynthetic activity was measured in leaves when the plant reached its physiological maturity (Kocal et al., 2008). A portable LI-COR 6400 meter (Lincoln, Nebraska, USA) was used, in each plant a healthy leaf of homogeneous color and free of damages was selected. A concentration of $400 \mu \mathrm{mol}$ per mole of $\mathrm{CO}_{2}$ was used in the reference cell, while the sample cell was maintained at approximately $380 \mu \mathrm{mol}$ per $\mathrm{ml}$ of $\mathrm{CO}_{2}$. The vapor pressure deficit of the air in the sample chamber was less than 1.5 and the block temperature that housed the sheet was $25^{\circ} \mathrm{C}$. Photosynthetic activity was expressed as $\mu \mathrm{mol}$ of $\mathrm{CO}_{2} \mathrm{~m}^{2} \cdot \mathrm{s}^{-1}$.

\section{SPAD values}

Chlorophyll readings were performed using the SPAD index (Soil Plant Analysis Development), using the SPAD-502 portable chlorophyllometer, which quantitatively evaluates the intensity of the green of the leaf (Cunha, 2015). Measurements were made in hours of high light, obtaining five random measurements per experimental unit. Two readings were made with the SPAD-502 meter, one on September 18, 2019 corresponding to the pre-flowering stage and the second on October 7, 2019 (Figure 5), and equivalent to the filling stage of pods.

\section{Photosynthetic pigments}

The method explained by Wellburn (1994) was used for the extraction and quantification of leaf pigments. Therefore, 10 leaf discs of seven millimeters in diameter of fresh photosynthetic plant material were required. $10 \mathrm{~mL}$ of pure methanol $\left(\mathrm{CH}_{3} \mathrm{OH}\right)$ were added. The samples were incubated for $24 \mathrm{~h}$ in the dark at room temperature. After this time, the absorbance was measured at $666 \mathrm{~nm}$ (chlorophyll a, chl a), $653 \mathrm{~nm}$ (chlorophyll b, chl b) and $470 \mathrm{~nm}$ (carotenoids). A blank containing only methanol was prepared. Pigment concentrations were expressed as mg.ml-1 fresh weight.

\section{Statistical analysis}

An analysis of variance and a mean separation test were performed using the LSD method using the SAS statistical package (SAS, 2004).

\section{Results and Discussion}

\section{Biomass and production}

Biomass is an indicator of the nutritional status of plants, since the yield of a crop is given by the ability to accumulate biomass in the organs that are destined for harvest (Peil and Gálvez, 2004). In the present experiment, significant differences were observed in the total biomass in dry weight (Figure 1), highlighting the foliar application dose of $50 \mathrm{ppm}$ of Nano Magnesium with the highest total biomass, with an increase of $25 \%$, $19 \%$ and $9 \%$ in relation to the Control and the doses of 200 and 100 ppm of Nano Magnesium respectively. The production of pods increased with the dose of $100 \mathrm{ppm}$, showing a higher level of average yield of $62 \%$, in relation to the dose of $50 \mathrm{ppm}$ where the minimum values were presented (Figure 2). For their part, the control plants and doses of $200 \mathrm{ppm}$ were kept 52 and $51 \%$ below the level of the best dose, respectively. 
The data obtained in the present work are very similar to those found by Stagnari et al. (2009), where foliar fertilization with magnesium in green beans (Phaseolus vulgaris $\mathrm{L}$.) increased aerial and root biomass, as well as pod yield. In the research of Mahawa et al. (2017), where they worked with $\mathrm{MgO}$ nanoparticles in mung beans (Vigna radiata L.), the data were also similar, finding that the doses of 50 and $100 \mathrm{mg.L} \mathrm{L}^{-1}$ of magnesium nanoparticles stimulated performance. Insufficient levels of $\mathrm{Mg}$, inhibit protein synthesis, generate lower content of chlorophyll and carotenoids, in addition to affecting the transport of assimilates to chloroplasts, sensitivity of demand organs and an increase in susceptibility to heat stress, among others; This leads to a decrease in performance (Mengel and Kirkby, 2000; Delfani et al., 2014; Singh et al., 2017). Several studies show that magnesium is an essential macronutrient in the photosynthetic process, likewise, an increase in its content increases the yield and quality of crops, in addition to being involved in carbohydrates and protein synthesis (Neuhaus and Mühling, 2014), as well as, in the translocation of assimilates towards sinks (Fischer and Bremer, 1993; Cakmak et al., 1994; Fischer et al., 1998; Shabala and Hariadi, 2005; Stagnari et al., 2009).

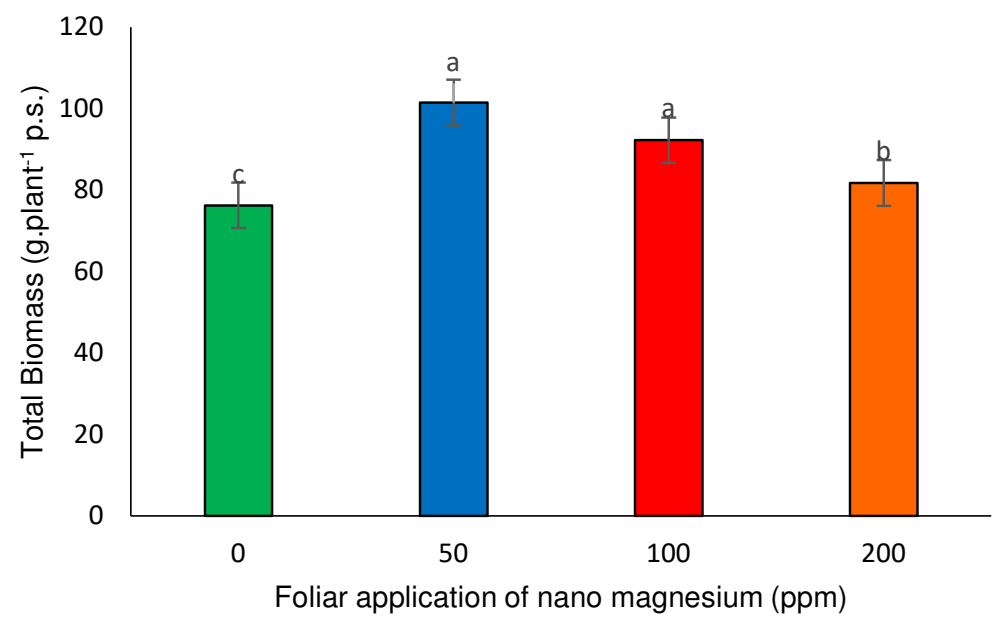

Figure 1. Total biomass in dry weight in the different treatments of Nano Magnesium via foliar route in bean plants cv. 'Strike'

The letters show significant statistical differences 


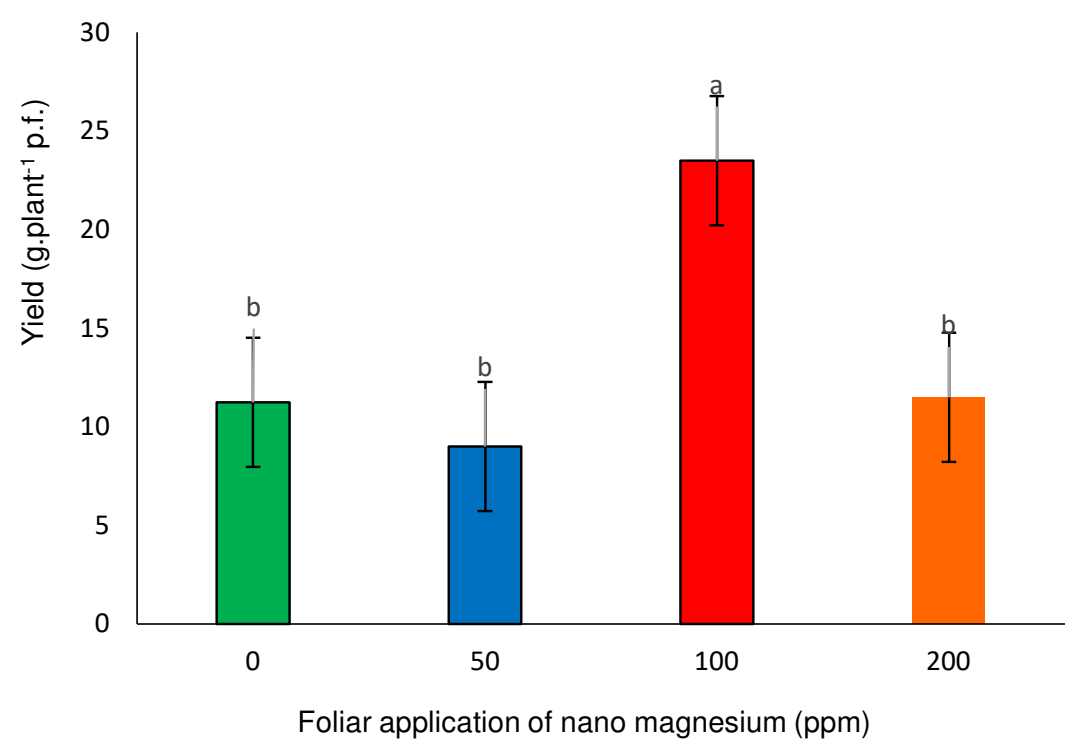

Figure 2. Effect of the application of Magnesium Nano fertilizer on the production of fruits in fresh weight in bean plants cv. 'Strike'

Letters show significant statistical differences

\section{Nitrate reductase enzyme activity "in vivo"}

Photosynthetic nitrate reductase activity is an enzyme that participates in the assimilation of nitrogen, since it is in charge of reducing nitrates $\left(\mathrm{NO}_{3}^{-}\right)$to nitrites $\left(\mathrm{NO}_{2}^{-}\right)$; It has been postulated by researchers as an important indicator of nitrogen nutrition status (Villalobos and Carvajal, 1978; Ruiz and Azcón, 1996; Neubauer et al., 1999; Maldonado, 2013; Meloni et al., 2017). In the present investigation, no significant differences were observed between the studied doses (Figure 3) that could be explained because the control plant did not have an Mg deficiency; however, the data obtained by the 100-ppm dose stand out with respect to the others by an average of 5\%. Meanwhile, Rathore and Tadafar (2015) applied $20 \mathrm{ppm}$ of magnesium nanoparticles in wheat and found significant results, increasing the nitrate reductase activity by $65 \%$. The activity of the enzyme nitrate reductase in plants is correlated with growth and yield (Srivastava, 1980). When applying the 100-ppm dose, an important relationship was found between the nutritional status of magnesium and nitrogen assimilation. Marschener (2012) mentions that a good level of the macronutrient Magnesium generates a higher proportion of protein and activates the enzyme glutamine synthetase; this is important for the efficient use of nitrogen. The existence of abundant nitrogen contributes to the formation of chlorophyll, which increases photosynthetic activity and therefore plant development (Raigón et al., 2006). 


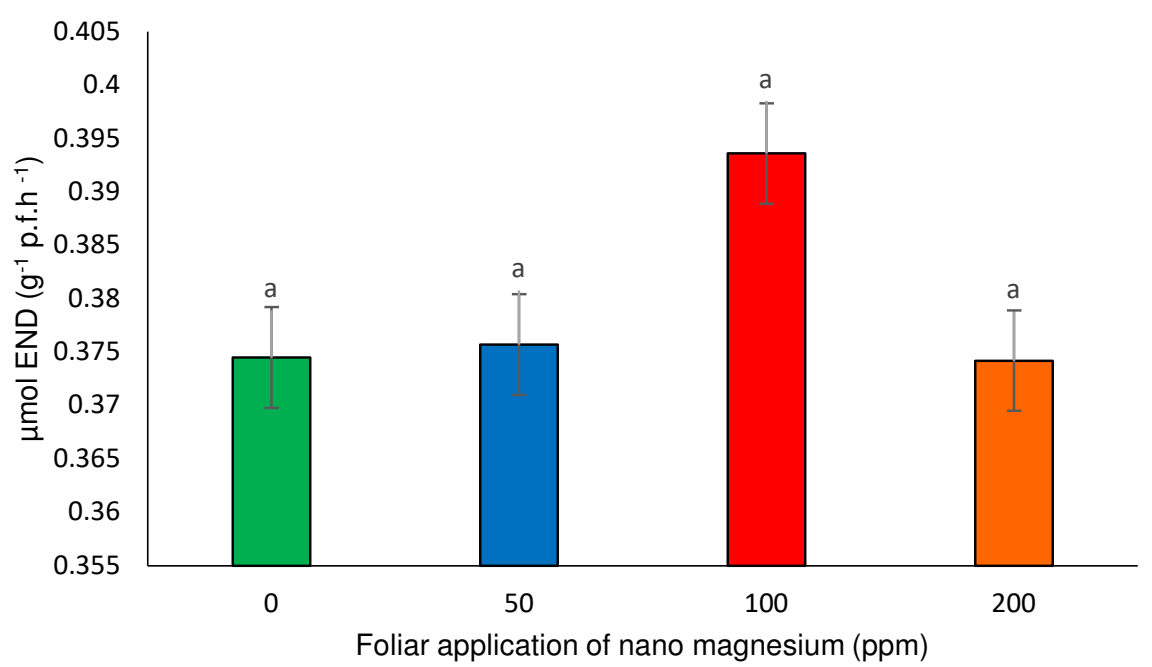

Figure 3. Endogenous Nitrate Reductase enzymatic activity because of the application of magnesium nanofertilizer in green bean cv. 'Strike'

\section{Photosynthetic activity}

Photosynthetic activity is a fundamental process for the development of crops because it is the main source of energy for plants, however, deficiencies in the magnesium supplement can affect this process and affect productivity (Azcón-Bieto et al., 2008; Farhat et al., 2016). In the present research work, no significant differences were obtained in terms of photosynthetic activity (Figure 4). However, the application of magnesium at doses of 50, 100 and $200 \mathrm{ppm}$ obtained increases of $16.31 \%, 53.94 \%$ and $61.36 \%$ respectively, in relation to the control. Several studies mention that a deficiency of $\mathrm{mg}$ affects the photosynthetic activity of plants, because it acts negatively on the enzyme ribulose-1,5-bisphosphate carboxylase/oxygenase (Rubisco) involved in the fixation of $\mathrm{CO}_{2}$, also, it has been shown that $\mathrm{Mg}$ deficiency induces a lower performance of the electron transport chain involved in photosystems, this being a very important factor in the decrease in $\mathrm{CO}_{2}$ uptake (Yang et al., 2012; Farhat et al., 2016). Finally, despite not obtaining the highest values in terms of photosynthetic activity, the dose of $100 \mathrm{ppm}$ obtained a higher production of pods, which may indicate that the plants were starting a maturation process as reported by Chávez-Simental and Álvarez-Reyna (2012) indicate that photosynthetic activity in beans decreases as the harvest period approaches. 


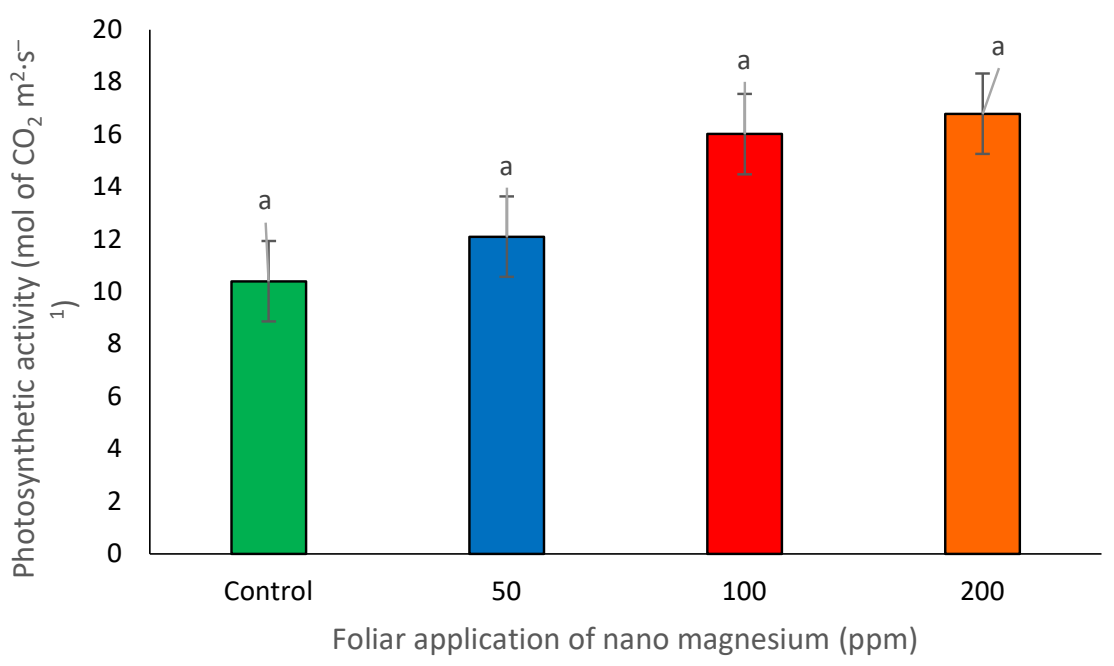

Figure 4. Photosynthetic activity because of the application of Magnesium nanofertilizer in green beans cv. 'Strike'

\section{$S P A D$ values}

The SPAD-502 Minolta portable device measures the transmission of red light at $650 \mathrm{~nm}$, and infrared light, at $940 \mathrm{~nm}$, which is highly correlated with chlorophyll content (Markwell et al., 1995; Guimarães et al., 1999; Gil et al., 2002). Magnesium is an essential element for chlorophyll, since it is found in the center of the tetrapyrrolic ring of the molecule (Romero, 1995). In the present study, for both cases, no significant statistical differences were found. However, it is observed that in the control the data were maintained; in the $100 \mathrm{ppm}$ treatment there was a 3\% drop; the $50 \mathrm{ppm}$ treatment had an increase of 5\%; and the $200 \mathrm{ppm}$ dose increased by $12 \%$. Possibly the variability between the data of the different doses was generated as a consequence of the sudden changes in the environmental conditions (drastic increases and decreases in temperature, heavy rains) that occurred during the establishment of the experiment, which could have generated this variability in the data. It is noticeable that, in all the treatments, the readings are lower than 40 units, which indicates, according to what Hendry and Price (1993) said, the beginning of a possible deterioration of the photosynthesis process, due to disturbances caused in the plants by environmental factors. 


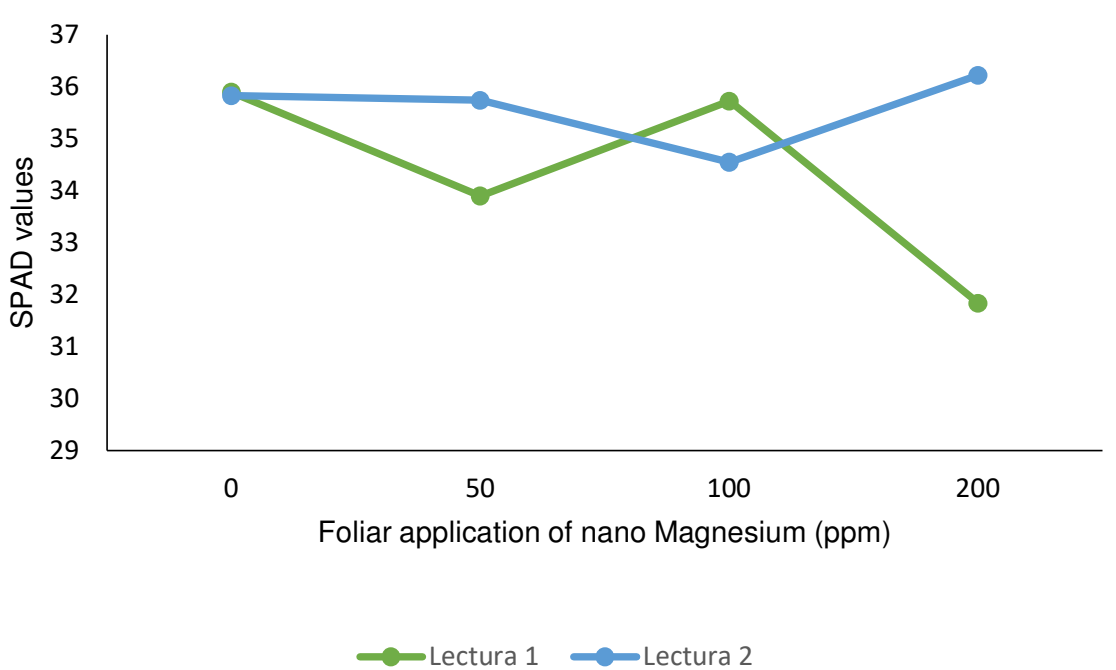

Figure 5. SPAD values, because of the application of Magnesium nanofertilizer in green bean cv. 'Strike' Reading 1, September 18, 2019 pre-flowering; reading 2, October 7, 2019 filled with pods

\section{Photosynthetic pigments}

The determination of the concentration of photosynthetic pigments is a useful parameter to evaluate the physiological state of plants (Casierra et al., 2012).

\section{Chlorophyll}

The present study revealed that the content of chlorophyll "a", "b" and total in bean leaves (Figures 6, 7 and 8 , respectively) is not statistically significant. However, a similar behaviour was observed in all three, with the highest data obtaining the dose with $50 \mathrm{ppm}$, followed by the dose of $200 \mathrm{ppm}$, and the lowest level was for the studies with $100 \mathrm{ppm}$ and $0 \mathrm{ppm}$. These results are quite similar to those found by Mahawar et al. (2017), where the measurement of the chlorophyll "a" content in mung bean plants (Vigna radiata L.) exposed to concentrations of 50 and $100 \mathrm{mg} . \mathrm{L}^{-1}$ revealed a significant increase. In turn, Neuhaus et al. (2013), found that in Vicia faba, both chlorophyll and photosynthesis concentrations increased after the application of $\mathrm{Mg}$.

Magnesium is essential in the photosynthetic process (for both light and dark reactions), specifically for the activity of two important $\mathrm{CO}_{2}{ }^{-}$binding enzymes, ribulose phosphate carboxylase and phosphoenolpyruvate carboxylase (Seftor et al., 1986; Stagnari et al., 2009; Romero, 1995). The increase in pigment content due to the foliar application of Nano Magnesium is explained as a consequence of an improvement in the size, structure and function of chloroplasts (including the transfer of electrons in photosystem II) (McSwaine et al., 1976), as well as a favourable absorption of light, photosynthetic activities and a greater release of enzymes to achieve the mobilization of nutrients, resulting in a better absorption of these and therefore in higher yield. Emphasizing, magnesium is the structural component of chlorophyll and many coenzymes; a small variation in its level strongly affects key photosynthetic enzymes (Mitra, 2015). 


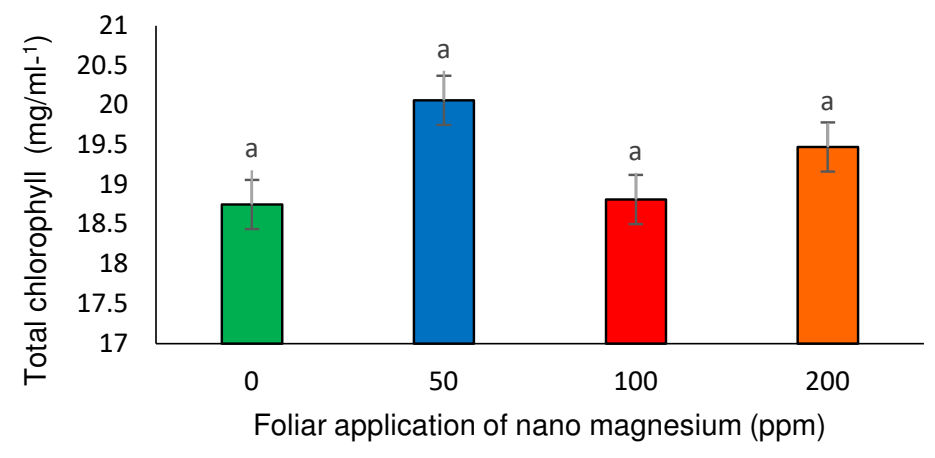

Figure 6. Total chlorophyll concentration in green bean leaf cv. 'Strike' as a result of foliar application of Magnesium Nanofertilizer

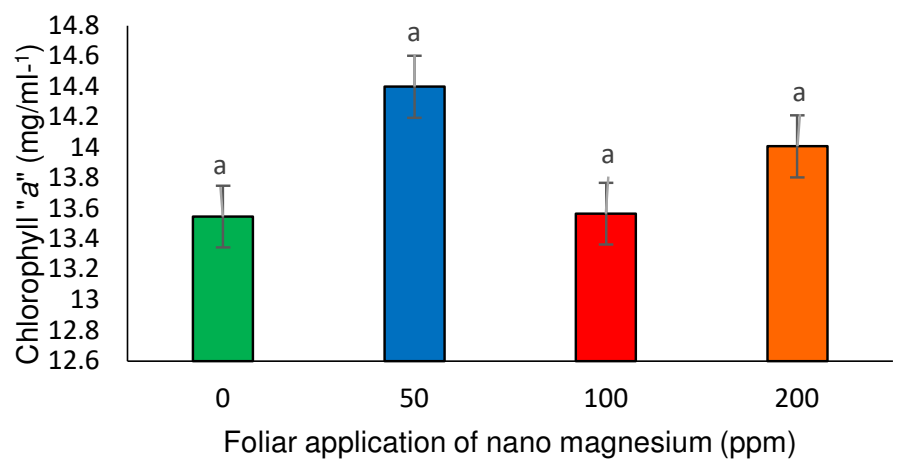

Figure 7. Chlorophyll concentration "a" as a result of foliar application of Magnesium Nanofertilizer on green bean leaf cv. 'Strike'

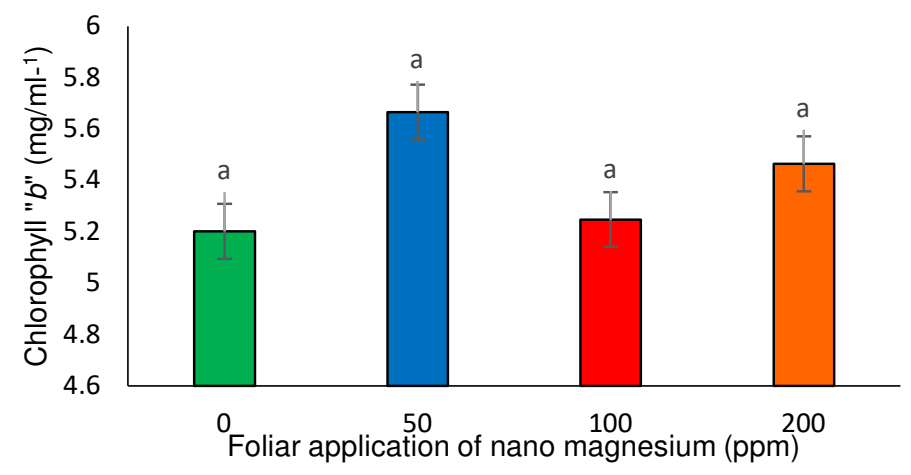

Figure 8. Chlorophyll "b" concentration in green bean leaf cv. 'Strike' as a result of the foliar application of Magnesium Nanofertilizer

\section{Carotenes}

In the case of carotenes (Figure 9), significant statistical differences were found, observing a decrease as the dose was higher, obtaining the dose of 200 ppm, $38 \%$ disadvantage with respect to the control. Meléndez 
et al. (2004) mention that these pigments are found in the chloroplasts of green tissues, where they are masked by chlorophyll until the tissue ages; the carotenoid content increases and the chlorophyll content decreases during the maturation of the plants. This means that, by increasing the dose of magnesium in the plants, the amount of carotenoids decreased, since the plants were less stressed against oxidative and photolytic damage, compared to the control that lacked Magnesium. Which agrees with what was said by (Casierra et al., 2012) in their work with calendula leaves, where the higher values found in the carotene/chlorophyll ratio, under high lighting conditions, would be the reflection of a greater synthesis of carotenes than chlorophylls, in order to protect tissues from oxidative stress caused by highly reactive oxygen radicals (ROS). These pigments fulfill the function of being photon collectors and act as accessory pigments in photosystems and as photoprotective agents that limit the damaging effects of high lighting (Johnson et al., 1993).

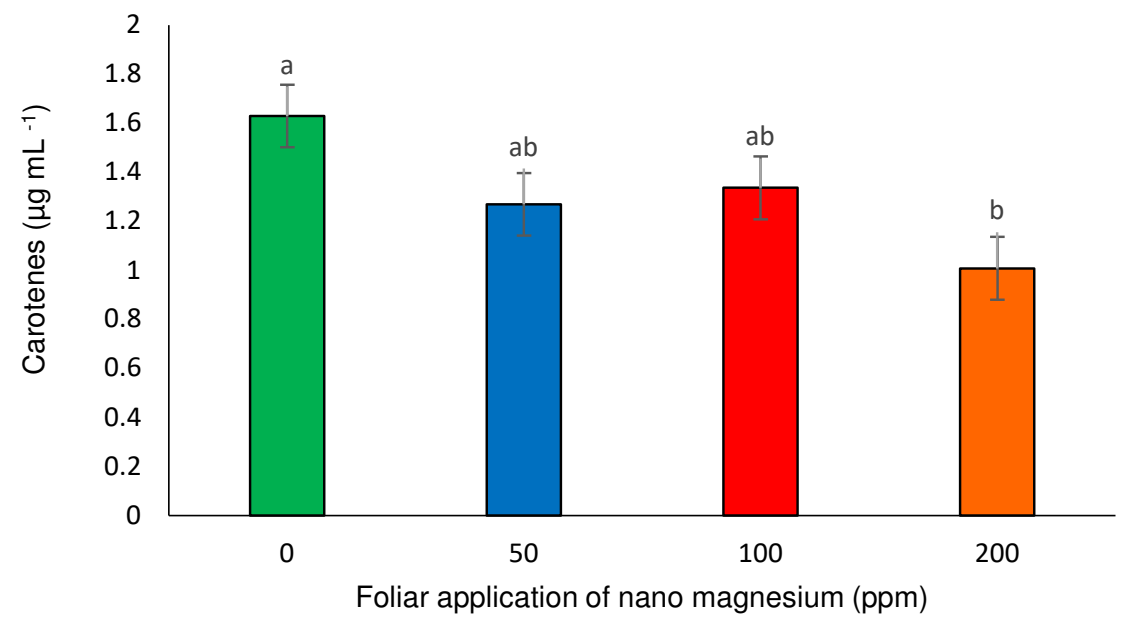

Figure 9. Carotene content as an effect of the application of Magnesium nanofertilizer in green bean $\mathrm{cv}$. 'Strike'

The letters show significant differences

\section{Conclusions}

The magnesium nanofertilizer doses that allowed obtaining the best parameters were 50 and $100 \mathrm{ppm}$. The first generated the highest amount of biomass and photosynthetic pigments, while the dose of $100 \mathrm{ppm}$ had better pods yield and a higher activity of the nitrate reductase enzyme, in addition to a higher photosynthetic activity. The present research work sought the dose of Nano Magnesium that offered a better physiological and production response, so the most appropriate application would result in $100 \mathrm{ppm}$. However, an investigation is suggested where a dose between 50 and $100 \mathrm{ppm}$ is included, in order to find the most appropriate dose, and work with a dose greater than $200 \mathrm{ppm}$ to find the values that are phytotoxic.

\section{Authors' Contributions}

Conceptualization: ES; Methodology: ASM, NIAO, APM; Validation: LPLT, SPA; Formal analysis: APM, PPR; Investigation: ASM, APM, NIAO; Data curation: ES, PPR; Funding acquisition: ES; Project administration: ES; Writing: ASM, ES; Review and editing: ASM, APM, ES; All authors read and approved the final manuscript. 


\section{Acknowledgements}

Alondra Salcido Martínez acknowledgements financial support given by Plant Physiology and Nutrition Laboratory of the Food and Development Research Center (CIAD Delicias).

\section{Conflict of Interests}

The authors declare that there are no conflicts of interest related to this article.

\section{References}

Azcón-Bieto J, Bou IF, Aranda X, Casanovas NG (2008). Fotosíntesis, factores ambientales y cambio climático. In: Fundamentos de fisiología vegetal [Photosynthesis, environmental factors and climate change. In: Fundamentals of plant physiology]. McGraw-Hill Interamericana de España pp 247-263.

Baethgen WE, Alley MM (1989). A manual colorimetric procedure for measuring ammonium nitrogen in soil and plant. Communications in Soil Science and Plant Analysis 20:961-969. https://doi.org/10.1080/00103628909368129

Butt BZ, Naseer I (2020). Nanofertilizers. In: Javad S (Ed). Nanoagronomy. Springer, Cham. https://doi.org/10.1007/978-3-030-41275-3_8

Cakmak I, Hengeler C, Marschner H (1994). Changes in phloem export of sucrose in leaves in response to phosphorus, potassium and magnesium deficiency in bean plants. Journal of Experimental Botany 278:1251-1257. https://www.jstor.org/stable/23694596

Cambrón VH, España ML, Sánchez NM, Sáenz C, Vargas JJ, Herrerías Y (2011). Producción de clorofila en Pinus pseudostrobus en etapas juveniles bajo diferentes ambientes de desarrollo [Chlorophyll production in Pinus pseudostrobus in juvenile stages under different development environments]. Revista Chapingo Serie Ciencias Forestales y del Ambiente 17(2):253-260. https://dx.doi.org/10.5154/r.rchscfa.2010.09.077

Cardona C, Flor CA, Morales F, Pastor MA (1995). Problemas de campo en cultivos de fríjol en el trópico. En: Centro Internacional de Agricultura Tropical (CIAT) [Field problems in bean crops in the tropics. In: International Center for Tropical Agriculture]. Cali, Colombia pp 1-5.

Casierra F, Ávila O, Riascos D (2012). Cambios diarios del contenido de pigmentos fotosintéticos en hojas de caléndula bajo sol y sombra [Daily changes of photosynthetic pigment content in calendula leaves under sun and shade]. Temas Agrarios 17(1):60-71. https://doi.org/10.21897/rta.v17i1.697

Centritto M, Loreto F, Chartzoulakis K (2003). The use of low [CO2] to estimate diffusional and non-diffusional limitations of photosynthetic capacity of sal-stressed olive saplings. Plan, Cell and Environment 26:585-594. https://doi.org/10.1046/j.1365-3040.2003.00993.x

Chávez-Simental JA, Alvarez-Reyna VDP (2012). Ecofisiología de seis variedades de frijol bajo las condiciones climáticas de la Región Lagunera [Ecophysiology of six bean varieties under the climatic conditions of the Lagoon Region]. Revista Mexicana de Ciencias Agrícolas 3(2):299-309.

Chhipa H (2016). Nanofertilizers and nanopesticides for agriculture. Environmental Chemistry Letters 15(1):15-22. https://doi.org/:10.1007/s10311-016-0600-4

Cunha A, Katz L, Sousa A, Martinez RA (2015). Indice SPAD en el crecimiento y desarrollo de plantas de lisianthus en función de diferentes dosis de nitrógeno en ambiente protegido [SPAD index in the growth and development of lisianthus plants as a function of different doses of nitrogen in a protected environment]. Idesia (Arica) 33(2):97-105. https://dx.doi.org/10.4067/S0718-34292015000200012

De la Fuente M, López M, Alonso J, Santalla M, De Ron A, Álvarez GZapata C (2012). Phaseolin Protein Diversity of Common Bean. Food Technology and Biotechnology 50 (3):315-325

Delfani M, Baradarn M, Farrokhi N, Makarian H (2014). Some Physiological Responses of Black-Eyed Pea to Iron and Magnesium Nanofertilizers. Communications in Soil Science and Plant Analysis 45(4):530-540. https://doi.org/10.1080/00103624.2013.863911 
Esquivel G, Acosta JA, Rosales R, Pérez P, Hernández JM, Navarrete R, Muruaga JS (2006). Productividad y adaptación del frijol ejotero en el Valle de México [Productivity and adaptation of the green bean in the Valley of Mexico]. Revista Chapingo Serie Horticultura 12(1):119-126.

Etchevers JD (1999). Técnicas de diagnóstico útiles en la medición de la fertilidad del suelo y el estado nutrimental de los cultivos [Useful diagnostic techniques in measuring soil fertility and the nutritional status of crops]. Terra Latinoamericana 17(3):209-219. https://www.redalyc.org/articulo.oa?id=573/57317305

Farhat N, Elkhouni A, Zorrig W, Smaoui A, Abdelly C, Rabhi M (2016). Effects of magnesium deficiency on photosynthesis and carbohydrate partitioning. Acta physiologiae plantarum 38(6):145. https://doi.org/10.1007/s11738-016-2165-Z

FIRA (2019). Fideicomisos Instituidos en Relación con la Agricultura. Retrieved 2020 August from https://www.inforural.com.mx/wp-content/uploads/2020/01/PanoramaAgroalimentario-Frijol-2019.pdf

Fischer ES, Bremer E (1993). Influence of magnesium deficiency on rates of leaf expansion, starch and sucrose accumulation, and net assimilation in Phaseolus vulgaris. Physiologia Plantarum 89(2):271-276.

https://doi.org/10.1111/j.1399-3054.1993.tb00153.x

Fischer ES, Lohaus G, Heineke D, Heldt HW (1998). Magnesium deficiency results in accumulation of carbohydrates and amino acids in source and sink leaves of spinach. Physiologia Plantarum 102(1):16-20.

https://doi.org/10.1034/j.1399-3054.1998.1020103.x

García FJ, Roselló-Caselles J, Santamarina MP (2006). Introducción al funcionamiento de las plantas. Editorial: Universidad Politécnica de Valencia. Valencia, España pp 181.

Johnson GN, Scholes JD, Horton P, Young AJ (1993). Relationshipsbetween carotenoid composition and growth habit in British plantspecies. Plant Cell Environment 16:681-686. https://doi.org/10.1111/j.1365-3040.1993.tb00486.x

Karacan S, Aslantas N (2008). Simultaneous preconcentration and removal of iron, chromium, nickel with N, N-etylenebis(ethane sulfonamide) ligand on activated carbon in aqueous solution and determination by ICP-OES Mehmet. Journal of Hazardous Materials 155:551-557. https://doi.org/10.1016/j.jhazmat.2007.11.107

Kaul RK, Kumar P, Burman U, Joshi P, Agrawal A, Raliya R, Tarafdar JC (2012). Magnesium and iron nanoparticles production using microorganisms and various salts. Materials Science Poland 30:254-258.

https://doi.org/10.2478/s13536-012-0028-X

Khan MN, Mobin M, Abbas ZK, AlMutairi KA, Siddiqui ZH (2017). Role of nanomaterials in plants under challenging environments. Plant Physiology and Biochemistry 110:194-209. https://doi.org/10.1016/j.plaphy.2016.05.038

Kocal N, Sonnewald U, Sonnewald S (2008). Cell wall-bound invertase limits sucrose export and is involved in sympton development and inhibition of photosynthesis during compatible interaction between tomato and Xanthomonas campestris pv vesicatoria. Plant Physiology 148:1523-1536. https://doi.org/10.1104/pp.108.127977

Liu R, Lal R (2015). Potentials of engineered nanoparticles as fertilizers for increasing agronomic productions. Science of The Total Environment 514:131-139. https://doi.org/10.1016/j.scitotenv.2015.01.104

Mahawar H, Prasanna R, Simranjit K, Thapa S, Kanchan A, Singh R, ... Nain L (2017). Deciphering the mode of interactions of nanoparticles with mung bean (Vigna radiata L.). Israel Journal of Plant Sciences 1-9. https://doi.org/10.1080/07929978.2017.1288516

Maldonado JM (2013). Asimulación del nitrógeno y del azufre [Assimilation of nitrogen and sulfur]. Azcón-Bieto. In Fundamentos de Fisiología Vegetal; Talón, M., Ed.; McGraw-Hill Interamericana: Madrid, España pp 287-304.

Marschener P (2012). Marschner's Mineral Nutrition of Higher Plants. San Diego, California, Estados Unidos de America: Academic Press.

Mauriño SG, Echevarria C, Mejias JA, Vargas MA, Maldonado JM (1986). Properties of the in vivo nitrate reductase assay in maize, soybean, and spinach leaves. Journal of Plant Physiology 124:123-130.

https://doi.org/10.1016/S0176-1617(86)80184-5

McSwain BD, Tsujimoto HY, Arnon DI (1976). Effects of magnesium and chloride ions on light-induced electron transport in membrane fragments from a blue-green alga. Biochimica et Biophysica Acta 423:313-322. https://doi.org/10.1016/0005-2728(76)90188-2

Meléndez AJ, Vicario IM, Heredia FJ (2004). Importancia nutricional de los pigmentos carotenoides. Archivos Latinoamericanos de Nutrición 54(2):149-155.

Meloni DA, Silva DM, Ledesma R, Bolzón GI (2017). Mineral nutrition and photosynthesis of Prosopis alba (Fabaceae) seedlings under saline stress. Cuadernos de Investigación UNED 9:297-304. 
Mengel K, Kirkby EA (2000). Principios de Nutrición Vegetal [Principals of vegetal nutrition]. Traducido 4a Edición por Melgar RJ, Ruz M. International Posh Institute. Bailea, Suiza pp 692.

Mitra GN (2015). REgulation of nutrient uptake by plants. New Delhi: Springer 10:978-981. https://doi.org/10.1007/978-81-322-2334-4

Neubauer H, Pantel I, Lindgren PE, Goetz F (1999). Characterization of the molybdate transport system ModABC of Staphylococcus carnosus. Archives of Microbiology 172:109-115. https://doi.org/10.1007/s002030050747

Neuhaus C, Geilfus CM, Mühling, KH (2014). Increasing root and leaf growth and yield in Mg-deficient faba beans ( Vicia faba) by MgSO4 foliar fertilization. Journal of Plant Nutrition and Soil Science 177(5):741-747. https://doi.org/10.1002/jpln.201300127

Peil RM, Gálvez JL (2004). Reparto de materia seca como factor determinante de la producción de las hortalizas de fruto cultivadas en invernadero [Distribution of dry matter as a determining factor in the production of fruit vegetables grown in greenhouses]. Revista Brasileira de Agrociencia 11(1):05-11.

Ponce CO, Soto JM, Sánchez E, Muñoz E, Piña FJ, Flores MA, Pérez R, Yañez-Muñoz RM (2019). Efficiency of nanoparticle, sulfate, and zinc-chelate use on biomass, yield, and nitrogen assimilation in green beans. Agronomy 9(3):128. https://doi.org/10.3390/agronomy9030128

Raigón MD, García MD, Guerrero C, Esteve P (2006). Actividad del nitrato reductasa y su relación con los factores productivos en lechuga. $\quad$ VII $\quad$ Congreso $\quad$ SEAE $\quad$ Zaragoza 2006. https://www.agroecologia.net/recursos/publicaciones/publicacionesonline/2006/CD\%20Congreso\%20Zaragoza/Po nencias/157\%20Raig\%C3\%B3n\%20Com-\%20Actividad.pdf

Rathore I, Tarafdar JC (2015). Perspectives of biosynthesized magnesium nanoparticles in foliar application of wheat plant. Journal of Bionanoscience 9(3):209-214. https://doi.org/10.1166/jbns.2015.1296

Romero L (1995). Algunos aspectos de la nutrición mineral de las plantas superiors [Some aspects of mineral nutrition of superior plants]. Placido Cuadros, Granada, España.

Ruiz-Lozano JM, Azcon R (1996). Mycorrhizal colonization and drought stress as factors affecting nitrate reductase activity in lettuce plants. Agriculture, Ecosystems \& Environment 60:175-181.

https://doi.org/10.1016/S0167-8809(96)01074-2

Sánchez E (2006). Caracterización del estado nutricional y fisiológico en plantas de judía (Phaseolus vulgaris L. cv. 'Stricke') sometidas a un estrés por nitrógeno [Characterization of the nutritional and physiological state in bean plants related to nitrogen stress]. Tesis doctoral. Pp 3-11.

SAS (2004). SAS/STAT Users Guide: Statics, Ver. 9.00; SAS Institute, Inc.: Cary, NC, USA; pp 1503.

Seftor REB, Bahr JT, Jensen RG (1986). Measurement of the enzyme-CO2-Mg2+ form of spinach ribulose 1,5-bisphosphate carboxylase/oxygenase. Plant Physiology 80:599-600. https://doi.org/10.1021/bi00871a025

Shabala S, Hariadi Y (2005). Effects of magnesium availability on the activity of plasma membrane ion transporters and lightinduced responses from broad bean leaf mesophyll. Planta 221(1):56-65. https://doi.org/10.1007/s00425-004-1425-0

Shang Y, Hasan MK, Ahammed GJ, Li M, Yin H, Zhou J (2019). Applications of nanotechnology in plant growth and crop protection: a review. Molecules 24(14):2558. https://doi.org/10.3390/molecules24142558

Shaul O (2002). Magnesium transport and function in plants: the tip of the iceberg. BioMetals 15:309-323. https://doi.org/10.1023/A:1016091118585

Shinde S, Paralikar P, Ingle AP, Rai M (2018). Promotion of seed germination and seedling growth of Zea mays by magnesium hydroxide nanoparticles synthesized by the filtrate from Aspergillus niger. Arabian Journal of Chemistry https://doi.org/10.1016/j.arabjc.2018.10.001

Silbernagel MJ, Janssen W, Davis JHC, Montes De Oca G (1991). Snap bean production in the tropics: implications for genetic improvement, pp. 835- 862. In: Common Beans: Research for Crop Improvement. Van Schoonhoven A, Voysest O (Eds.). C.A.B. International. Wallingford, U.K. and CIAT, Cali, Colombia.

Singh-Diwakar B, Charmi V, Desai HG (2017). Effect of magnesium nanoparticles on physiology and stevioside in Stevia rebaudiana Bertoni.

Srivastava HS (1980). Regulation of nitrate reductase activity in higher plants. Phytochemistry 19(5):725-733. https://doi.org/10.1016/0031-9422(80)85100-4

Solanki P, Bhargava A, Chhipa H, Jain N, Panwar J (2015). Nanofertilizers and their smart delivery system. Nanotechnologies in Food and Agriculture 81-101. https://doi.org/10.1007/978-3-319-14024_7_4 
Stagnari F, Onofri A, Pisante M (2009). Response of French bean (Phaseolus vulgaris L.) cultivars to foliar applications of magnesium. Italian Journal of Agronomy 4(3):101. https://doi.org/10.4081/ija.2009.3.101

Ustin SL, Smith MO, Jacquemoud S, Verstraete MM, Govaerts Y (1998). GeoBotany: vegetation mapping for earth sciences, in manual of remote sensing, remote sensing for the earth sciences ( $3^{\text {rd }}$ ed). Rencz AN (Ed). John Wiley, Hoboken NJ 3:189248.

Villalobos E, Carvajal JF (1978). In método para analizar la actividad de la nitrato reductasa del nitrato en condiciones de campo [In method for analysing nitrate reductase activity of nitrate under field conditions]. Agronomia Costarricense 2(1):6981.

Wellburn AR (1994). The spectral determination of chlorophylls a and b as well total carotenoids, using various solvents whit spectrophotometer of different mresolution. Journal of Plant Physiology 144:307-313. http://dx.doi.org/10.1016/S0176-1617(11)81192-2

White PJ, Broadley MR (2009). Biofortification of crops with seven mineral elements often lacking in human diets - iron, zinc, copper, calcium, magnesium, selenium and iodine. New Phytologist 182(1):49-84.

https://doi.org/10.1111/j.1469-8137.2008.02738.x

Wolf B (1982). A comprehensive system of leaf analyses and its use for diagnosing crop nutrient status. Communications in Soil Science and Plant Analysis 13(12):1035-1059. https://doi.org/10.1080/00103628209367332

Yang GH, Yang LT, Jiang HX, Li Y, Wang P, Chen LS (2012). Physiological impacts of magnesium-deficiency in Citrus seedlings: photosynthesis, antioxidant system and carbohydrates. Trees 26(4):1237-1250. http://dx.doi.org/10.1007/s00468-012-0699-2

Zhang Y, Chen JM, Thomas SC (2007). Retrieving seasonal variation in chlorophyll content of overstory and understory sugar maple leaves from leaf level hyperspectral data. Canadian Journal of Remote Sensing 33(5):406-415. https://doi.org/10.5589/m07-037
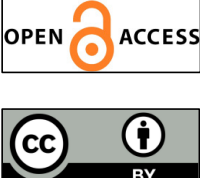

The journal offers free, immediate, and unrestricted access to peer-reviewed research and scholarly work. Users are allowed to read, download, copy, distribute, print, search, or link to the full texts of the articles, or use them for any other lawful purpose, without asking prior permission from the publisher or the author.

License - Articles published in Notulae Botanicae Horti Agrobotanici Cluj-Napoca are Open-Access, distributed under the terms and conditions of the Creative Commons Attribution (CC BY 4.0) License. (c) Articles by the authors; UASVM, Cluj-Napoca, Romania. The journal allows the author(s) to hold the copyright/to retain publishing rights without restriction. 